\title{
The Effect of Audit Objectives on Audit Quality-Why is There Little Disclosure of Significant Deficiencies in Japanese Internal Control Audits?
}

\author{
Hiroshi Uemura \\ Kochi University of Technology, Kochi, Japan
}

\begin{abstract}
Many prior research findings indicate that audit quality differs between the Big 4 and non-Big 4 audit firms using an indicator variable. However, most previous research focuses on only outcome measures, such as audit fees, going concern reports, and non-audit services. This study investigates audit quality differentiation between the Big 4 and non-Big 4 audit firms hypothesis from an audit objective point of view. One of the material objectives of Japanese internal control audit institutions is to facilitate assessment and improvement of internal controls by corporations themselves. The findings of this study indicate that the Big 4 audit firms accomplish this objective better than non-Big 4 audit firms. Consequently, most Big 4 clients do not disclose significant deficiencies (SDs), implying that they improve the quality of internal controls through internal controls auditing. This paper concludes that Big 4 firms produce a higher audit quality level than non-Big 4 firms, and this quality difference is related to how an audit objective is interpreted and implemented.
\end{abstract}

Keywords: audit quality, internal control audit, significant deficiencies (SDs), audit firm size

\section{Introduction}

Financial reporting and disclosure are important institutional features that facilitate the flow of information (Nanda \& Wysocki, 2011). Also, a legal institution affects firms' financial reporting incentives and the quality of financial information reported to investors. The Financial Instruments and Exchange Act of 2006 (J-SOX) requires top management of all listed Japanese companies to report their assessment of the company's internal controls and to present audit reports confirming the validity of their assessment (Sections 24 and 193). ${ }^{1}$ In addition, J-SOX requires management to disclose the existence of all significant deficiencies (SDs) at fiscal year-end. However, even after J-SOX enforcement, serious accounting scandals (e.g., Olympus and Toshiba) occur frequently. As a result of these cases, social criticism has been leveled at firms about audit quality.

J-SOX has given rise to a significant research question in Japanese audit research: why are SDs in internal controls less frequent in Japan than in the US? Nishizaki, Takano, and Takeda (2014) explained this phenomenon in terms of a difference in source of law. Japan is a unique code-law country that employs an internal control reporting system similar to Section 404 of the Sarbanes-Oxley Act of 2002 (US-SOX). Leuz,

Hiroshi Uemura, associate professor, School of Economics and Management, Research Center for Future Design, Research Institute, Kochi University of Technology. Email: uemura@seiyagroup.com.

${ }^{1} \mathrm{~J}$-SOX does not require auditors to directly assess the effectiveness of companies' internal controls. Instead, auditors must judge the validity of management's assessment. That is, auditors must express their opinion of whether management's report is accurate based on evidence they gather themselves. 
Nanda, and Wysocki (2003) suggested that both legal and enforcement institutions in a country are significant determinants of firms' reporting quality. Ball, Kothari, and Robin (2000) found that corporations from countries with common-law institutions exhibit more timely loss recognition than in code-law countries. This institutional view indicates that the disclosure of internal control weakness (ICW) may be less frequent in Japan than in the US (Nishizaki et al., 2014). Also, Nanda and Wysocki (2011) suggested that the informativeness of firms' financial reports is affected by regulations that mandate accounting disclosures as well as by investors' and other stakeholders' demand for information. This study focuses on the institutional differences, because firms' disclosure practices are affected by managerial choices made in response to the institutional environment (e.g., regulations or standards that mandate financial reporting) within a country.

The quality of financial reporting is also affected by the audit quality. High-quality external auditing is a central component of well-functioning capital markets (Skinner \& Srinivasan, 2012). The accounting literature focuses on two principal forces that motivate auditors to deliver quality a litigation/insurance incentive and a reputation incentive (Skinner \& Srinivasan, 2012). The first motive is connected with minimization of the cost of litigation, and the second motive is related to audit fees (pricing) in the market for audit services. To reduce the litigation risk and to increase reputation in the market, audit firms must enhance audit quality. DeAngelo (1981, p. 186) defined audit quality as "the market assessed joint probability that a given auditor will both discover a breach in a client's accounting system, and report the breach". This definition can be taken apart into two components (Knechel, Krishnan, Pevzner, Shefchik, \& Velury, 2013). The first component is related to an auditor's competence and level of effort, and the second component is linked to an auditor's objectivity, professional skepticism, and independence. Moreover, some researchers interpret audit quality as an auditor's competence of error detection (e.g., Chan \& Wong, 2002; Chang, Dasgupta, \& Hilary, 2009). On the other hand, some literatures define audit quality in terms of the auditing practices. Auditors should perform the audit in accordance with audit institution (auditing standards). Therefore, at least, we can be sure that the level of audit quality depends on the extent which auditors perform the audit in accordance with auditing standards. ${ }^{2}$ Finally, Francis (2011) classified analysis that influences audit quality into six levels, including audit inputs, audit processes, accounting firms, audit industry and audit market, institutions, and economic consequences of audit outcomes. This study assumes that audit institutions have an effect on audit input, audit processes. Also, because audit outcomes depend on the audit inputs and audit processes, audit inputs and audit processes have an effect on economic consequences (e.g., audit fees). In sum, economic consequences that an audit institution produces depend on the institutional features (e.g., main objective of an audit institution).

J-SOX does not require auditors to assess the effectiveness of clients' internal controls directly. Instead, auditors must judge the validity of the management report. That is, based on audit evidence that auditors must obtain themselves, they express their opinion on whether the management report is fair. Therefore, it can be said that Japanese internal control audits do not adopt direct reporting. Clients are able to submit much evidence that supports the assertion by top management to external auditors. Such a situation may influence making beliefs of auditors in internal control auditing. An objective of J-SOX has a unique feature. An objective of J-SOX showed by standard setters is to facilitate assessment and improvement of internal controls by corporations themselves (Business Accounting Council, 2010) ${ }^{3}$. It is difficult to assume that audit firms do not consider an audit objective that standard setters expect. If audit quality is defined as "degrees of

\footnotetext{
2 Material deviations from the standards are presumed to reflect poor audit quality (Knechel et al., 2013).

3 The 18th Internal Control Committee Meetings in June 2010.
} 
understanding and accomplishing an objective of an audit institution" in Japanese internal control audits, auditors have to help facilitate improving internal controls by corporations to enhance audit quality. This study investigates the level of the quality of internal controls audit in terms of accomplishment of an audit objective.

Blokdijk, Drieenhuizen, Simunic, and Stein (2006) found that Big 5 auditors allocate relatively more effort to planning and control risk assessment, and relatively less to substantive testing and completion. This means that Big 5 auditors spend relatively more time relating controls to substantive tests. On the other hand, non-Big 5 audit firms spend relatively more time on substantive audit testing. Therefore, Big 5 audit firms respond to high-quality clients' internal controls in a reasonable way. By contrast, the greater the degree of reliance on a client's internal controls by non-Big 5 auditors, the greater the total hours these firms spend on engagements (Blokdijk et al., 2006). ${ }^{4}$ Based on their findings and theory, Big 4 audit firms identify in the early phase of an internal control audit the possibility that SDs exist in internal controls (e.g., audit planning or internal control assessment phase), and thus, the Big 4 audit firms are able to work on prompting the clients to improve the SDs before the end of the fiscal year. By contrast, to identify SDs by non-Big 4 audit firms, it is necessary to extend the extent of applying substantive tests, or to increase the frequency of substantive tests. Moreover, it is difficult to assume that non-Big 4 audit firms help facilitate improving SDs, because non-Big 4 audit firms have relatively less audit resources than Big 4 audit firms. In summary, because the amount of audit resources and how to use the audit resources of Big 4 audit firms differ from non-Big 4 audit firms, audit outcomes differ between Big 4 audit firms and non-Big 4 audit firms. To test this argument, this study investigates whether audit quality differs between Big 4 and non-Big 4 audit firms, and analysis disclosure of SDs, and the increase in terms of accomplishment of an audit objective.

This study investigates audit quality differentiation between the Big 4 and non-Big 4 audit firms hypothesis from an audit objective point of view. The findings of this study indicate that the Big 4 audit firms accomplish this objective better than non-Big 4 audit firms. Consequently, most Big 4 clients do not disclose SDs, implying that they improve the quality of internal controls through internal controls auditing. This paper thus concludes that Big 4 firms produce a higher audit quality level than non-Big 4 firms, and this quality difference is related to how an audit objective is interpreted and implemented.

\section{Hypotheses}

As stated in the introduction, an objective of J-SOX is to facilitate assessment and improvement of internal controls by corporations themselves (Business Accounting Council, 2010). To accomplish this objective, J-SOX has some unique standards and requirements. For example, in J-SOX, deliberation between top management and external auditors concerning the extent of internal control assessment is recommended to be scheduled as soon as possible (J-SOX Practical Guideline 4). In addition, if auditors detect SDs through internal control audits, they should require top management to improve the SDs (J-SOX Practice Standards III. 4(3)), because if SDs exist in the financial reporting process, the SDs must be improved compared to the early stage to ensure an appropriate financial reporting process (J-SOX Practice Standards III. 4(2)).

If audit quality is defined from an audit objective point of view, high-quality auditing could help facilitate the improvement of internal controls by corporations themselves. As a result, SDs are not disclosed at fiscal year-ends, because the SDs may have been improved by the fiscal year-end. In addition, if Big 4 audit quality

\footnotetext{
${ }^{4}$ Blokdijk et al. (2006) suggested that this is contrary to textbook auditing theory and auditing standards, since an audit firm should choose to rely on a client's internal controls only when it is efficient to do so.
} 
in Japanese internal control audits is higher than that of non-Big 4 audit firms, as suggested in previous studies, the possibility that Big 4 clients disclose SDs becomes lower. This argument leads to the following hypothesis:

H1: Audit firm size (Big 4 audit firms/non-Big 4 audit firms indicator variable) has a negative correlation with SD disclosure.

Blokdijk et al. (2006) found that Big 5 auditors allocate relatively more effort to planning and control risk assessment, and relatively less to substantive testing and completion. On the other hand, non-Big 5 auditors spend relatively more time on substantive audit testing. They concluded that non-Big 5 audit firms increase total audit time when relying on clients' strong internal controls. In other words, total audit resources of non-Big 5 audit firms increase when SDs are detected through internal control audits. However, audit resources of Big 5 audit firms increase when they facilitate improving material problems in internal controls perceived in audit planning or control assessments. Therefore, the audit fees of Big 4 clients are expected to increase with SD improvements, while the audit fees of non-Big 4 clients are expected to increase with SD detection (disclosure). In addition, because disclosed SDs of Big 4 clients could not have been improved before fiscal year-ends, the audit fees of their clients may not increase. ${ }^{5}$ These arguments lead to the following hypotheses:

H2a: The disclosure of SDs of Big 4 clients is not associated with audit fees.

$\mathrm{H} 2 \mathrm{~b}$ : The disclosure of SDs of Big 4 clients is positively associated with audit fees.

\section{Models}

The following model testing H1 is based on Ge and McVay (2005), Ashbaugh-Skaife, Collins, and Kinney (2007), and Doyle, Ge, and McVay (2007):

$$
\begin{gathered}
\text { SD }_{t}=f\left(\beta_{0}+\beta_{1} \text { Big }_{t}+\beta_{2} \text { LNSize }_{t}+\beta_{3} M \& A_{t}+\beta_{4} \text { LNSub }_{t}+\beta_{5} \text { ForeignSales }_{t}\right. \\
+\beta_{6} \text { ROA }_{t}+\beta_{7} \text { Restate }_{t}+\beta_{8} \text { GC }_{t}+\beta_{9} \text { CfoA }_{t}+\beta_{10} \text { Found }_{t} \\
+ \\
\left.+\beta_{11} \text { LNDirector }_{t}+\beta_{12} \text { Office }_{t}+\beta_{13} \text { ExeChange }_{t}\right)
\end{gathered}
$$

The dependent variable $\left(S D_{t}\right)$ is an indicator variable equal to 1 if a corporation discloses an SD in year $t$ and 0 if otherwise. The independent variable $\left(B i g 4_{t}\right)$ is an indicator variable equal to 1 if a corporation engages a Big 4 audit firm in year $t$ and 0 if otherwise. $B i g 4_{t}$ is expected to be positively correlated with $S D_{t}$ after controlling for other variables, thereby supporting H1. Moreover, this study identifies the quality of internal controls using a discriminant based on Model (1). ${ }^{6}$ Previous studies have clarified the determinants of the disclosure of SDs: company size, complexity, financial risk, and audit firms' size (Ge \& McVay, 2005; Ashbaugh-Skaife et al., 2007; Doyle et al., 2007; Ogneva, Subramanyam, \& Raghunandan, 2007). However, in Japan, few companies have disclosed SDs after introducing internal control audits. In fact, of the 2,437 listed companies that submitted management reports for the fiscal year ending March 2009 (the first year of internal control audits), only 57 (2.33\%) disclosed SDs. ${ }^{7}$ In the US literature, non-disclosure of SDs means high quality,

\footnotetext{
${ }^{5}$ Such situations include, for example, Big 4 auditors detecting SDs just before fiscal year-ends, or SDs detected by Big 4 auditors being very serious (e.g., the SDs cause material misstatements in financial statements). Thus, the SDs cannot be improved before fiscal year-ends.

${ }^{6}$ The prior probability that a company belongs to the SDs disclosure group $\left(\omega_{1}\right)$ is on condition that the discrimination function (model for the disclosure of SDs) (z) is given as: $p\left(\omega_{1} \mid z\right)=p\left(\omega_{1}\right) p\left(z \mid \omega_{1}\right)=p(X) p\left(\omega_{1} \mid z\right)$, where $z=S D_{t}=$ Model (1). Therefore, the posterior probability that a company belongs to $\left(\omega_{1}\right)$ is: $p\left(\omega_{1} \mid z\right)=\frac{p\left(\omega_{1}\right) p\left(z \mid \omega_{1}\right)}{p(z)}$. This study computes PSD (the posterior probability of SD disclosure) of any company based on the equation, not the disclosure of SDs, to identify internal control quality. ${ }^{7}$ In the US, $23.5 \%$ of companies disclosed material weaknesses in the first year.
} 
not low quality, of internal controls. However, it is difficult to believe that the quality of internal controls of most Japanese companies is high from the beginning. Rather, most low-quality companies may have improved their SDs by fiscal year-ends through internal control auditing. To distinguish high-quality companies from low-quality companies, but not disclosed SDs, this study identifies the threshold for low-quality internal controls based on the US result as $20 \%$ (the posterior probability of SDs existing is $20 \%$; hereafter, PSD (20\%)), because the ratio of the number of companies with $20 \%$ probability to the full sample is $15.7 \%$.

On the other hand, the following model testing $\mathrm{H} 2 \mathrm{a}$ and $\mathrm{H} 2 \mathrm{~b}$ is based on Raghunandan and Rama (2006), R. Hoitash, U. Hoitash, and Bedard (2008), Krishnan, Rama, and Zhang (2008), Feldmann, Read, and Abdolmohammadi (2009), and Hammersley, Meyers, and Zhou (2012):

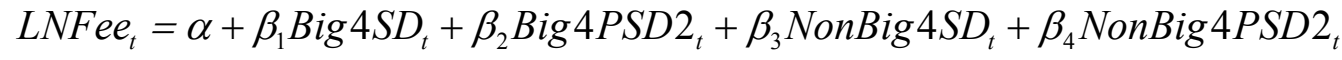

$$
\begin{aligned}
& +\beta_{5} \text { LNSize }_{t}+\beta_{6} \text { ROA }_{t}+\beta_{7} \text { GC }_{t}+\beta_{8} \text { LNSub }_{t}+\beta_{9} \text { ForeignSales }_{t}+\beta_{10} M \& A_{t} \\
& +\beta_{11} \text { Inv }_{t}+\beta_{12} \text { Big }_{t}+\beta_{13} \text { AudChange }_{t}+\beta_{14} \text { LNnas }_{t}+\beta_{15} \text { SEC }_{t}+\varepsilon
\end{aligned}
$$

The dependent variable $\left(L N F e e_{t}\right)$ is the natural logarithm of audit fees in year $t$. In addition, $B i g 4 S D_{t}$,

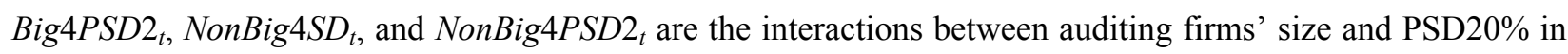

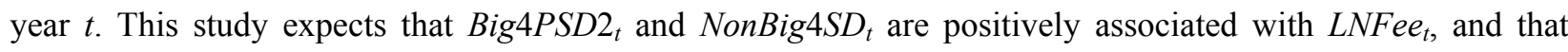
$\mathrm{Big}_{4 S D_{t}}$ and NonBig $4 P S D 2_{t}$ are not associated with $L N F e e_{t}$, thereby supporting $\mathrm{H} 2 \mathrm{a}$ and $\mathrm{H} 2 \mathrm{~b}$.

The definitions of all variables used in Models (1) and (2) are shown in Table 1.

Table 1

\begin{tabular}{|c|c|}
\hline Variable & Definition \\
\hline$S D_{t}$ & An indicator variable equal to 1 if the firm discloses a material weakness in year $t$, and 0 if otherwise. \\
\hline$B i g 4_{t}$ & An indicator variable equal to 1 if a firm is audited by a Big 4 audit firm in year $t$, and 0 if otherwise. \\
\hline LNSize $_{t}$ & The natural logarithms of total assets in year $t$. \\
\hline$M \& A_{t}$ & An indicator variable equal to 1 if a firm is involved in a merger or acquisition in year $t, 0$ if otherwise. \\
\hline$L N S u b_{t}$ & The natural $\log$ of $(1+$ the number of subsidiaries $)$ in year $t$. \\
\hline ForeignSales $_{t}$ & The proportion of the foreign sales on total sales in year $t$. \\
\hline$R O A_{t}$ & The return on assets in year $t$. \\
\hline Restate $_{t}$ & The number of financial restatements reported in year $t$. \\
\hline$G C_{t}$ & $\begin{array}{l}\text { An indicator variable equal to } 1 \text { if the firm reports the explanatory notes regarding the going concern } \\
\text { assumption in year } t \text {, and } 0 \text { if otherwise. }\end{array}$ \\
\hline$C F O / A_{t}$ & The operating cash flow deflated by total assets in year $t$. \\
\hline Found $_{t}$ & The number of years since a corporation was founded in year $t$. \\
\hline LNDirector $_{t}$ & The natural logarithm of total number of directors in year $t$. \\
\hline Office $_{t}$ & The average of tenure of directors in year $t$. \\
\hline ExeChange $_{t}$ & An indicator variable equal to 1 if there is chief executive turnover in year $t$, and 0 if otherwise. \\
\hline$P S D 2_{t}$ & $\begin{array}{l}\text { An indicator variable equal to } 1 \text { if a posterior probability of SD disclosure of a corporation is } 20 \% \text { or more in } \\
\text { year } t \text {, and } 0 \text { if otherwise. }\end{array}$ \\
\hline $\mathrm{NonBig}_{t}$ & An indicator variable equal to 1 if a firm is audited by a non-Big 4 audit firm in year $t$, and 0 if otherwise. \\
\hline$B i g 4 * S D_{t}$ & The interaction between Big 4 and SD in year $t$. \\
\hline Big4*PSD2 ${ }_{t}$ & The interaction between Big 4 and PSD2 in year $t$. \\
\hline NonBig4*SD & The interaction between Non-Big 4 and SD in year $t$. \\
\hline NonBig4*PSD2 ${ }_{t}$ & The interaction between Non-Big 4 and PSD2 in year $t$. \\
\hline $\operatorname{Inv} v_{t}$ & The inventory/total assets in year $t$. \\
\hline AudChange $_{t}$ & An indicator variable equal to 1 if a corporation replaces an audit firm in year $t$. \\
\hline LNnas $_{t}$ & The natural $\log$ of $(1+$ non-audit service fees $)$ in year $t$. \\
\hline$S E C_{t}$ & An indicator variable equal to 1 if a firm adopts US SEC standards. \\
\hline
\end{tabular}

Definitions of Variables 


\section{Sample and Data}

Table 2 (Panel A) describes the sample selection procedure.

Table 2

Sample Selection Procedure

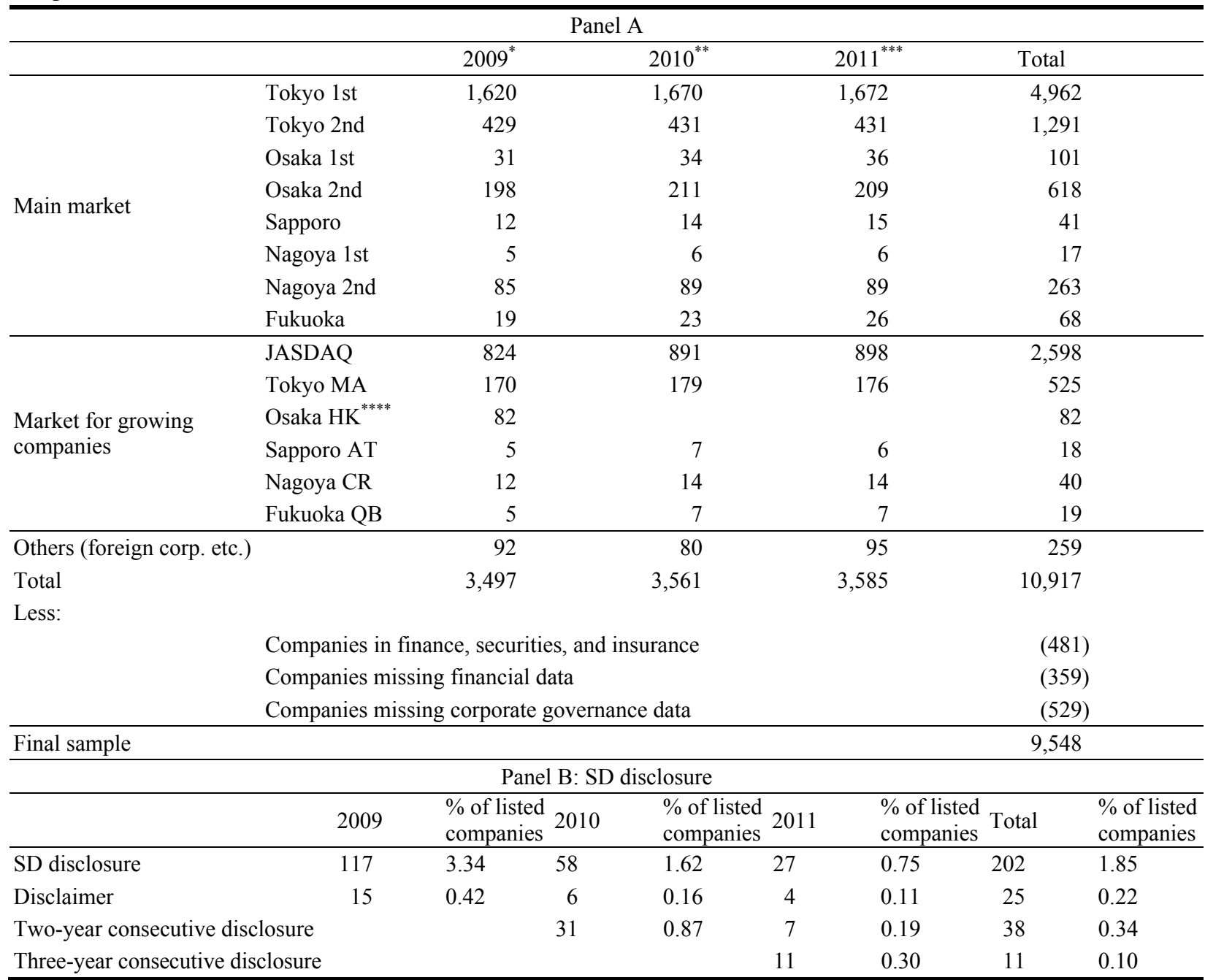

Note. " : 2009 period is from March 31, 2009 to December 31, 2010; ${ }^{* *}: 2010$ period is from January 1, 2010 to December 31, $2010 ;^{* * *}: 2011$ period is from January 1, 2011 to December 31, 2011; and ${ }^{* * * *}$ : Osaka HK was integrated into JASDAQ in 2010 .

Our investigation documented 10,917 firm-year observations of publicly traded Japanese companies that disclosed management reports for fiscal years ending March 31, 2009 to December 31, 2011. ${ }^{8}$ We excluded 481 observations for companies in the finance, securities, insurance, and other industries because their financial statements differ markedly from most companies, 359 observations because they were missing financial data, ${ }^{9}$ and 529 observations for foreign firms and firms with no corporate governance; thus, the final sample contains 9,548 firm-year observations. Financial data are from NEEDS Financial QUEST. Data related

8 J-SOX came into force for all listed companies at the end of March 2009. Therefore, this study's sample period spans 2009-2011.

9 We excluded 108 observations for outlying data identified by Tukey box plotting. 
to management's internal control reports, audit reports, and numbers of business segments are from EDINET. Data for CEO replacements and boards of directors are from Directors' Quarterly Journals (Toyo Keizai Shinposya).

Table 2 (Panel B) reports the number of corporations that disclosed SDs during the sample period. In 2009 (the first year of an audit of internal controls over financial reporting in Japan), 117 corporations (3.34\%) disclosed SDs, and 15 could not report the results of their management's assessments. In 2010, 58 corporations (1.62\%) disclosed SDs, 6 issued disclaimers, and 31 companies disclosed SDs for the second consecutive year.

\section{Results}

\section{Descriptive Statistics}

Table 3 shows descriptive statistics. First, Big 4 clients are less likely to disclose SDs than non-Big 4 clients $\left(S D_{t}, p<0.001\right)$, and the posterior possibility of SD disclosure of Big 4 clients is lower than that of non-Big 4 clients $\left(P S D 2_{t}, p<0.001\right)$. The results indicate that the quality of internal controls of Big 4 clients is higher than that of non-Big 4 clients, thus supporting H1. Second, on average, audit fees and non-audit service fees of the Big 4 are higher than those of the non-Big 4 (LNFee , LNnas $_{t}, p<0.001$ ). Moreover, size (total assets) of Big 4 clients on average is larger, and ROA of Big 4 clients is higher $\left(\right.$ LNSize $_{t}, \mathrm{ROA}_{t}$, $p<0.001)$. On the other hand, the possibility that non-Big 4 clients report going-concern reports is higher $\left(G C_{t}\right.$, $p<0.001)$.

Table 3

Descriptive Statistics

\begin{tabular}{|c|c|c|c|c|c|c|c|}
\hline \multirow{2}{*}{ Variable } & \multicolumn{3}{|c|}{ Big 4 group $(N=7,105)$} & \multicolumn{3}{|c|}{ Non-Big 4 group $(N=2,443)$} & \multirow{2}{*}{$\begin{array}{l}\text { Differences } \\
t \text { or } \chi^{2}\end{array}$} \\
\hline & Mean & Median & Std. dev. & Mean & Median & Std. dev. & \\
\hline$\overline{S D}$ & 0.01 & 0.01 & 0.09 & 0.03 & 0.03 & 0.17 & $-6.32^{* * *}$ \\
\hline PSD2 & 0.08 & 0.08 & 0.27 & 0.34 & 0.34 & 0.47 & $-25.31^{* *}$ \\
\hline Audit Fees & 66.67 & 35.01 & 143.87 & 31.15 & 24.04 & 38.79 & $12.02^{* * *}$ \\
\hline LNFee & 3.71 & 3.55 & 0.78 & 3.22 & 3.17 & 0.56 & $28.45^{* * *}$ \\
\hline LNSize & 10.53 & 10.34 & 1.72 & 9.67 & 9.57 & 1.53 & $21.83^{* * *}$ \\
\hline$R O A$ & 1.08 & 1.83 & 8.08 & -12.29 & 1.24 & 32.93 & $2.56^{* * *}$ \\
\hline$G C$ & 0.01 & 0.01 & 0.11 & 0.08 & 0.08 & 0.27 & $-12.12^{* * *}$ \\
\hline$L N S u b$ & 1.89 & 1.82 & 1.35 & 1.54 & 1.54 & 1.06 & $12.01^{* * *}$ \\
\hline ForeignSales & 10.66 & 0.40 & 20.45 & 7.44 & 0.28 & 17.55 & $6.93^{* * *}$ \\
\hline$M \& A$ & 0.07 & 0.07 & 0.26 & 0.07 & 0.07 & 0.25 & 0.95 \\
\hline AudChange & 0.01 & 0.01 & 0.08 & 0.09 & 0.09 & 0.28 & $-13.48^{* *}$ \\
\hline LNnas & 0.41 & 0.26 & 0.89 & 0.08 & 0.05 & 0.43 & 17.54 \\
\hline$S E C$ & 0.01 & 0.01 & 0.10 & 0.00 & 0.00 & 0.05 & $5.70^{* * *}$ \\
\hline
\end{tabular}

Note. $^{* * *},{ }^{* *}$, and ${ }^{* * *}$ indicate two-tailed significance at the levels of $0.10,0.05$, and 0.01 respectively.

Table 4 reports the correlation matrix of each variable included in Models (1) and (2). It is notable from the results in Table 4 that the interactions between Big 4 and SD and between Big 4 and PSD2 are positively correlated with audit fees, while the interaction between non-Big 4 and SD is not. Moreover, the interaction between non-Big 4 and PSD2 is negatively correlated with audit fees. These results indicate that when Big 4 clients have a low quality of internal controls, even if Big 4 clients do not disclose SDs, audit fees increase. However, unless non-Big 4 clients disclose SDs, audit fees do not increase, but rather decrease. These results 
indicate that although substantive testing procedures of non-Big 4 audit firms increase to detect SDs (audit fees of non-Big 4 clients increase when SDs are detected), the audit fees of Big 4 clients increase when control risk is high. ${ }^{10}$

Table 4

Correlation Matrix (Spearman/Pearson)

\begin{tabular}{|c|c|c|c|c|c|c|c|c|c|c|c|c|c|c|c|c|}
\hline & 1 & 2 & 3 & 4 & 5 & 6 & 7 & 8 & 9 & 10 & 11 & 12 & 13 & 14 & 15 & 16 \\
\hline 1 & 1.000 & $0.309^{* * *}$ & 0.016 & $0.046^{* * *}$ & $-0.214^{* *}$ & $-0.164^{* * *}$ & $0.806^{* * *}$ & 0.008 & $-0.069^{* * *}$ & $0.742^{* * * *}$ & $-0.112^{* * *}$ & $-0.068^{* * *}$ & -0.22 & 0.02 & 0.07 & 0.013 \\
\hline 2 & $0.283^{* * *}$ & 1.000 & $0.044^{* * *}$ & $0.150^{* * *}$ & $-0.151^{* * *}$ & $-0.524^{* * *}$ & $0.221^{* * *}$ & $0.114^{* * *}$ & $-0.179^{* * *}$ & $0.112^{* * *}$ & $0.070^{* * * *}$ & 0.010 & -0.007 & $-0.211^{* * *}$ & $0.203^{* * *}$ & $0.043^{* * *}$ \\
\hline 3 & $0.021^{* *}$ & $0.044^{* * *}$ & 1.000 & $-0.019^{*}$ & -0.007 & $-0.023^{* *}$ & 0.010 & -0.001 & 0.013 & $0.025^{* *}$ & $-0.035^{* *}$ & 0.011 & $-0.049^{* * *}$ & $0.081^{* * *}$ & -0.011 & $-0.08 \mathrm{~s}$ \\
\hline 4 & $0.040^{* * *}$ & $0.150^{* * *}$ & $-0.019^{*}$ & 1.000 & $-0.023^{* *}$ & $-0.079^{* * *}$ & $-0.085^{* * *}$ & $-0.130^{* * *}$ & $-0.181^{* * *}$ & -0.015 & $-0.042^{* * *}$ & $0.024^{* *}$ & -0.012 & $0.071^{* * *}$ & -0.003 & $-0.050^{\circ}$ \\
\hline 5 & -0.016 & $-0.151^{* * *}$ & -0.007 & $-0.023^{* *}$ & 1.000 & $-0.028^{* *}$ & $-0.085^{* * *}$ & $-0.130^{* * *}$ & $0.181^{* * *}$ & -0.015 & $0.433^{* * *}$ & $-0.424^{* * *}$ & $-0.128^{* * *}$ & $0.110^{* * *}$ & $0.243^{* * *}$ & $0.221^{* * *}$ \\
\hline 6 & $-0.183^{* * *}$ & $-0.524^{* * *}$ & $-0.023^{* *}$ & $-0.079^{* * *}$ & $-0.028^{* *}$ & 1.000 & $-0.233^{* * *}$ & -0.009 & $0.317^{* * *}$ & $-0.058^{* * *}$ & $-0.049^{* * *}$ & -0.002 & $-0.049^{* * *}$ & $0.025^{* *}$ & $0.067^{* * *}$ & 0.010 \\
\hline 7 & $0.771^{* * *}$ & $0.221^{* * *}$ & 0.002 & $-0.035^{* *}$ & $-0.073^{* * *}$ & $-0.231^{* * *}$ & 1.000 & $0.055^{* * *}$ & $-0.198^{* * *}$ & $0.732^{* * *}$ & $0.179^{* * *}$ & $-0.165^{* * *}$ & $-0.060^{* * *}$ & $-0.050^{* * *}$ & $0.094^{* * *}$ & $0.072^{* * *}$ \\
\hline 8 & $0.026^{* *}$ & $0.027^{* *}$ & $-0.054^{* * *}$ & $-0.050^{* * *}$ & $-0.097^{* * *}$ & $-0.137^{* * *}$ & $0.063^{* * *}$ & 1.000 & $-0.078^{* * *}$ & 0.008 & $0.306^{* * *}$ & $-0.318^{* * *}$ & $-0.162^{* * *}$ & $0.159^{* * *}$ & $0.241^{* * *}$ & $0.123^{* * *}$ \\
\hline 9 & $-0.076^{* * *}$ & $-0.179^{* * *}$ & 0.013 & $0.165^{* * *}$ & $0.181^{* * *}$ & $0.317^{* * *}$ & $-0.187^{* * *}$ & $-0.160^{* * *}$ & 1.000 & $-0.080^{*}$ & -0.001 & 0.008 & 0.010 & $-0.422^{* * *}$ & 0.020 & 0.02 \\
\hline 10 & $0.693^{* * *}$ & $0.123^{* * *}$ & $0.028^{* *}$ & $0.039^{* * *}$ & -0.012 & $-0.051^{* * *}$ & $0.693^{* * *}$ & $-0.047^{* * *}$ & $-0.085^{* * *}$ & 1.000 & $-0.096^{* * *}$ & 0.011 & $-0.089^{* * *}$ & $0.181^{* * *}$ & $-0.017^{*}$ & $-0.179^{* * * *}$ \\
\hline 11 & $0.279^{* * *}$ & $0.072^{* * *}$ & 0.010 & $0.036^{* *}$ & -0.005 & $-0.046^{* * *}$ & $0.280^{* * *}$ & $-0.072^{* * *}$ & $-0.043^{* * *}$ & $0.379^{* * *}$ & 1.000 & 0.008 & $0.115^{* * *}$ & $-0.020^{*}$ & $0.150^{* * *}$ & $0.094^{* * *}$ \\
\hline 12 & $0.091^{* * *}$ & 0.010 & -0.003 & $0.075^{* * *}$ & $0.031^{* *}$ & $0.056^{* * *}$ & $0.057^{* * *}$ & $0.028^{* *}$ & 0.006 & $0.112^{* * *}$ & 0.005 & 1.000 & $-0.021^{* *}$ & -0.011 & $0.090^{* * *}$ & $0.067^{* * *}$ \\
\hline 13 & $0.140^{* * *}$ & $-0.036^{* * *}$ & 0.002 & 0.003 & -0.001 & -0.006 & $0.198^{* * *}$ & $-0.124^{* * *}$ & 0.005 & $0.124^{* * *}$ & $0.254^{* * *}$ & $-0.026^{* *}$ & 1.000 & $0.041^{* * *}$ & -0.004 & -0.008 \\
\hline 14 & $-0.084^{* * *}$ & $-0.211^{* * *}$ & -0.003 & $0.051^{* * *}$ & $0.096^{* * *}$ & $0.385^{* * *}$ & $-0.102^{* * *}$ & $-0.047^{* * *}$ & $0.131^{* * *}$ & $-0.045^{* * *}$ & $-0.022^{* *}$ & -0.011 & $0.022^{* *}$ & 1.000 & $-0.038^{* * *}$ & -0.016 \\
\hline 15 & $0.331^{* * *}$ & $0.179^{* * *}$ & $0.002^{* * *}$ & $0.054^{* * *}$ & $-0.027^{* *}$ & $-0.108^{* * *}$ & $0.344^{* * *}$ & $0.084^{* * *}$ & $-0.056^{* * *}$ & $0.304^{* * *}$ & $0.121^{* * *}$ & $0.069^{* * *}$ & $0.027^{*}$ & $-0.045^{* * *}$ & $1.000^{* * *}$ & $0.273^{* * *}$ \\
\hline 16 & $0.163^{* * *}$ & $0.043^{* * *}$ & -0.007 & $0.017^{*}$ & -0.009 & $-0.026^{* *}$ & $0.156^{* * *}$ & $0.025^{* *}$ & $-0.017^{*}$ & $0.150^{* * *}$ & $0.068^{* * *}$ & $0.067^{* * *}$ & 0.007 & -0.016 & $0.163^{* * *}$ & 1.000 \\
\hline
\end{tabular}

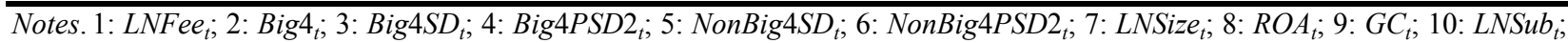

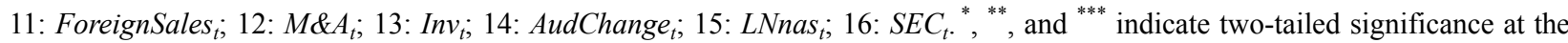
levels of $0.10,0.05$, and 0.01 respectively.

\section{Regression Results}

Table 5 (Panel A) shows the logistics regression result based on Model (1). First, Big $4_{t}$ has a negative correlation with $S D_{t}$, and this result supports H1 (Big $\left.4_{t}, p<0.017\right)$. This indicates that non-Big 4 auditors are less likely to help facilitate improving SDs by corporations to enhance audit quality than Big 4 auditors. With regard to the other variables, $L N$ Size $_{t}$ and $R O A_{t}$ have negative correlations with $S D_{t}$,

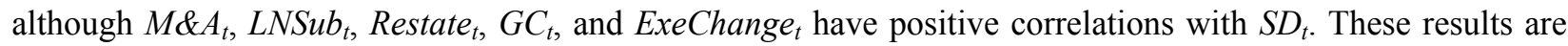
the same as those in previous studies (e.g., Ge \& McVay, 2005; Ashbaugh-Skaife et al., 2007; Doyle et al., 2007).

Table 5 (Panel B) reports the ordinary least squares (OLS) regression result based on Model (2). ${ }^{11}$ First, $B i g 4 P S D 2_{t}$ is positively correlated with $L N F e e_{t}$, while $B i g 4 S D_{t}$ is not. On the other hand, NonBig $4 S D_{t}$ has a positive correlation with $L N F e e_{t}$, although NonBig4PSD2 ${ }_{t}$ does not. These findings indicate that the audit fees of Big 4 clients increase with SD improvements, while the audit fees of non-Big 4 clients increase with SD detection (disclosure), that is, Big 4 auditors help facilitate the improvement of internal controls by corporations to enhance audit quality. This means that the audit quality of Big 4 audit firms is relatively high, because they accomplish the objective of internal control audit well.

\footnotetext{
${ }^{10}$ These results support the logic used to explain the findings of Blokdijk et al. (2006).

11 The largest Variance Inflation Factor (VIF) is 1.49
} 
Table 5

Regression Analysis

\begin{tabular}{|c|c|c|c|c|c|}
\hline \multirow{3}{*}{ Variable } & \multirow{3}{*}{$\begin{array}{l}\text { Predicted } \\
\text { sign }\end{array}$} & \multicolumn{2}{|c|}{$\begin{array}{l}\text { Logistic regression } \\
\text { Model (1) }\end{array}$} & \multicolumn{2}{|c|}{$\begin{array}{c}\text { OLS regression } \\
\text { Model (2) }\end{array}$} \\
\hline & & \multicolumn{2}{|c|}{ Panel A: DV $=S D_{t}$} & \multicolumn{2}{|c|}{ Panel B: DV $=L N F e e$} \\
\hline & & Coeff. & Wald & Coeff. & $t$-value \\
\hline Constant & & -2.397 & $3.724^{* *}$ & 0.630 & $18.460^{* * *}$ \\
\hline$B i g 4 S D_{t}$ & & & & 0.007 & 0.792 \\
\hline$B i g 4 P S D 2_{t}$ & + & & & 0.218 & $2.150^{* *}$ \\
\hline${\text { NonBig } 4 S D_{t}}$ & + & & & 0.042 & $7.592^{* * *}$ \\
\hline${\text { NonBig } 4 P S D 2_{t}}_{1}$ & & & & 0.004 & 0.258 \\
\hline $\mathrm{Big}_{t}$ & - & -0.483 & $7.694^{* * *}$ & 0.152 & $3.124^{* * *}$ \\
\hline LNSize $_{t}$ & - & -0.122 & $3.899^{* *}$ & 0.529 & $22.84^{* * *}$ \\
\hline$R O A_{t}$ & - & -0.001 & $3.293^{*}$ & -0.017 & $-3.290^{* * *}$ \\
\hline$G C_{t}$ & + & 2.542 & $10.252^{* * *}$ & 0.067 & $11.552^{* * *}$ \\
\hline$L_{N S u b}$ & + & 0.199 & $3.724^{* *}$ & 0.282 & $24.46^{* * *}$ \\
\hline ForeignSales $_{t}$ & + & 0.002 & 0.774 & -0.012 & 0.148 \\
\hline$M \& A_{t}$ & + & 0.278 & $3.351^{*}$ & 0.015 & $2.901^{* *}$ \\
\hline$C f o A_{t}$ & - & -0.011 & 1.248 & 0.314 & $3.035^{* *}$ \\
\hline Found $_{t}$ & + & -0.001 & 0.707 & 0.054 & 0.554 \\
\hline LNDirector $_{t}$ & + & -0.480 & 1.876 & -0.080 & -0.738 \\
\hline Office $_{t}$ & $?$ & -0.042 & 2.265 & 0.129 & 1.442 \\
\hline ExeChange $_{t}$ & + & 0.217 & $4.682^{* *}$ & 0.180 & $1.902^{*}$ \\
\hline $\operatorname{In} v_{t}$ & + & & & 0.152 & 0.795 \\
\hline Restate $_{t}$ & + & 0.603 & $4.882^{* *}$ & & \\
\hline AudChange $_{t}$ & + & & & -0.001 & -0.015 \\
\hline LNnas $_{t}$ & + & & & 0.082 & $13.775^{* * *}$ \\
\hline$S E C_{t}$ & + & & & 0.133 & $24.332^{* * *}$ \\
\hline Industry indicator & & Included & & Included & \\
\hline Year indicator & & Included & & Included & \\
\hline$N$ & & 9,548 & & 9,548 & \\
\hline Prob. $>x^{2}$ & & 0.000 & & & \\
\hline$-2 \log$ likelihood ratio & & 27.442 & & & \\
\hline Pseudo $R^{2}$ & & 0.354 & & & \\
\hline Adjusted $R^{2}$ & & & & 0.751 & \\
\hline$F$-value & & & & 1.869 & \\
\hline
\end{tabular}

Note.,$"$, and ${ }^{* * *}$ indicate two-tailed significance at the levels of $0.10,0.05$, and 0.01 respectively.

\section{Additional Analysis}

The results presented in Section 5 suggest that Big 4 firms help facilitate improvement of SD during the fiscal year. Therefore, SDs of Big 4 firms' clients were disclosed because they were unable to improve SDs before the fiscal year-end as a result of the SDs having been detected near the fiscal year-end. If so, Big 4 auditors help facilitate improvement of $S D_{t}$ in year $t+1$, and $S D_{t}$ has a positive correlation with changes in audit fees. In this section, to ensure the robustness of the previous results, the author investigates the relationship between SD disclosure in year $t$ and the changes in audit fees from year $t$ to year $t+1$ by using the following Model (3). The author uses 6,233 firm-years from 2009 (first year of J-SOX) to 2010 as a sample. 


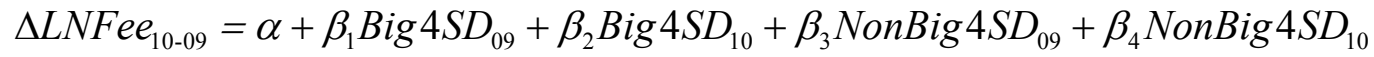

$$
\begin{aligned}
& +\beta_{5} \Delta \text { LNSize }_{10-09}+\beta_{6} \Delta R O A_{10-09}+\beta_{7} G_{10}+\beta_{8} \Delta L N S u b_{10-09}+\beta_{9} \Delta \text { ForeignSales }_{10-09} \\
& +\beta_{10} M \& A_{10}+\beta_{11} \Delta \operatorname{Inv} v_{10-09}+\beta_{12} \text { Big }_{10}+\beta_{13} \text { AudChange }_{10} \\
& +\beta_{14} \Delta \text { LNnas }_{10-09}+\beta_{15} S E C_{10}+\varepsilon
\end{aligned}
$$

Table 6 shows the OLS regression result based on Model (3). ${ }^{12} B i g 4 S D_{09}$ has a positive correlation with $\Delta$ LNFee $_{10-09}$, although NonBig $4 S D_{10}$ is positively correlated with $\Delta L N F e e_{10-09}$. The result means that Big 4 auditors help facilitate improving previous $\mathrm{SDs}\left(S D_{09}\right)$ in the next fiscal year.

\begin{tabular}{|c|c|c|c|}
\hline \multirow{3}{*}{ Variable } & \multirow{3}{*}{ Predicted sign } & \multicolumn{2}{|c|}{$\begin{array}{l}\text { OLS regression } \\
\text { Model (3) }\end{array}$} \\
\hline & & \multicolumn{2}{|c|}{$\mathrm{DV}=C H A N G E F E E(2009-2010)$} \\
\hline & & Coeff. & $t$-value \\
\hline Constant & & 0.053 & $4.952^{* * *}$ \\
\hline$B i g 4 S D_{09}$ & + & 0.025 & $2.428^{* *}$ \\
\hline$B i g 4 S D_{10}$ & & 0.002 & 0.068 \\
\hline NonBig $4 S D_{09}$ & & 0.019 & 0.972 \\
\hline NonBig $4 S D_{10}$ & + & 0.045 & $2.482^{* *}$ \\
\hline$B i g 4_{10}$ & + & 0.051 & $3.689^{* * *}$ \\
\hline$\Delta$ LNSize $_{10-09}$ & + & 0.097 & $4.935^{* * *}$ \\
\hline$\triangle R O A_{10-09}$ & - & -0.018 & -0.962 \\
\hline$G C_{10}$ & + & 0.018 & $1.942^{*}$ \\
\hline$\Delta L N S u b_{10-09}$ & + & 0.004 & 0.023 \\
\hline$\Delta$ ForeignSales $_{10-09}$ & + & -0.224 & -1.228 \\
\hline$M \& A_{10}$ & + & 0.019 & 1.065 \\
\hline$\Delta \operatorname{In} v_{10-09}$ & + & 0.036 & $1.988^{*}$ \\
\hline$\Delta$ AudChange $_{10}$ & + & -0.075 & -1.255 \\
\hline$\Delta$ LNnas $_{10-09}$ & + & -0.165 & $-4.192^{* * *}$ \\
\hline$S E C_{10}$ & + & 0.145 & $1.997^{*}$ \\
\hline Industry indicator & & Included & \\
\hline$N$ & & 6,233 & \\
\hline Adjusted $R^{2}$ & & 0.151 & \\
\hline$F$-value & & $12.93(p<0.001)$ & \\
\hline
\end{tabular}

Table 6

Regression Analysis

Note. ${ }^{,{ }^{\prime \prime *}}$, and ${ }^{* * * *}$ indicate two-tailed significance at the levels of $0.10,0.05$, and 0.01 respectively.

\section{Conclusion}

This study investigates the hypotheses of audit quality differentiation between Big 4 audit firms and non-Big 4 audit firms from an audit objective point of view. The findings indicate that the Big 4 audit firms accomplish audit objectives better than the non-Big 4 audit firms. J-SOX has a unique objective showed by standard setters: to facilitate assessment and improvement of internal controls by corporations themselves. If audit quality is defined as "degrees of understanding and accomplishing an objective of an audit institution", auditors must help facilitate improving internal controls by corporations to enhance audit quality.

12 The largest VIF is 1.87 . 
The findings indicate that Big 4 auditors make an effort to help facilitate improving SDs by companies themselves, leading to an increase in audit fees of Big 4 clients with low quality of internal controls (when there is no disclosure of SDs). On the other hand, non-Big 4 auditors have to use more audit resources (substantive testing) to detect SDs, while the audit resources of the non-Big 4 are relatively lower than those of the Big 4 . Therefore, audit fees of non-Big 4 audit clients increase only when the clients disclose SDs. The author concludes that Big 4 audit firms produce higher levels of audit quality, and this quality difference is related to how audit objectives are interpreted and implemented.

The findings have important implications for regulators and auditing standards setters. J-SOX was introduced following serious accounting fraud (e.g., Kanebo), because regulators and standard setters assume that some companies do not design and operate effective internal controls over financial reporting. However, even after J-SOX enforcement, serious accounting scandals (e.g., Olympus, Toshiba) occur. When such scandals occur, external auditors bear the brunt of social criticism, but these are rare cases, and the findings of this study in fact indicate that the quality of internal controls of most Japanese companies might improve after J-SOX. ${ }^{13}$ In addition, most Japanese companies emphasized improvement of the quality of internal controls after J-SOX; in fact, in the first fiscal year of J-SOX, the average (median) of audit fees of 3,756 Japanese listed companies increased by $53 \%$ (49\%) compared to the previous year. In addition, out of 1,314 companies that disclosed non-audit service fees, 1,087 companies paid advisory costs concerning internal controls.

If the fact that there is little disclosure of SDs in internal control audits is regarded as a negative phenomenon, then this should not be blamed on auditors. Rather, it should become a design matter to be dealt with by internal control audit standard setters. Therefore, the frequency differences of SD disclosures between J-SOX and the US SOX are not associated with institutional differences, but rather audit objective differences.

There are some limitations in this study. First, this study does not explain the reason why the change in audit fees of non-Big 4 firms with SDs disclosures does not increase in next year. Also, some audit firms' characteristics (e.g., industry expertise) are not included in the models used in this study.

\section{References}

Ashbaugh-Skaife, H., Collins, D. W., \& Kinney, Jr., W. R. (2007). The discovery and consequences of internal control deficiencies prior to SOX-mandated audits. Journal of Accounting and Economics, 44(1-2), 166-192.

Ball, R., Kothari, S. P., \& Robin, A. (2000). The effect of international institutional factors on properties of accounting earnings. Journal of Accounting and Economics, 29(1), 1-51.

Blokdijk, H., Drieenhuizen, F., Simunic, D. A., \& Stein, M. T. (2006). An analysis of cross-sectional differences in big and non-big public accounting firms' audit programs. Auditing: A Journal of Practice \& Theory, 25(1), 27-48.

Business Accounting Council. (2010). The record proceedings of The 18th Internal Control Committee Meetings. June 2010. Retrieved from http://www.fsa.go.jp/singi/singi_kigyou/top_gijiroku.html\#naibu

Chan, D. K., \& Wong, K. P. (2002). Scope of auditors' liability, audit quality, and capital investment. Review of Accounting Studies, 7(1), 97-122.

Chang, X., Dasgupta, S., \& Hilary, G. (2009). The effect of auditor quality on financing decisions. The Accounting Review, 84(4), $1085-1117$.

DeAngelo, L. E. (1981). Auditor size and audit quality. Journal of Accounting and Economics, 3(3), 183-199.

Doyle, J. T., Ge, W., \& McVay, S. (2007). Accruals quality and internal control over financial reporting. The Accounting Review, 82(5), 1141-1170.

Feldmann, D. A., Read, W. J., \& Abdolmohammadi, M. J. (2009). Financial restatements, audit fees, and the moderating effect of CFO turnover. Auditing: A Journal of Practice \& Theory, 28(1), 205-223.

${ }^{13}$ Francis (2011) suggested that there are relatively few cases of detectable audit failures. 
Francis, J. R. (2011). A framework for understanding and researching audit quality. Auditing: A Journal of Practice \& Theory, $30(2), 125-152$.

Ge, W., \& McVay, S. (2005). The disclosure of material weaknesses in internal control after the Sarbanes-Oxley Act. Accounting Horizons, 19(3), 137-158.

Hammersley, J. S., Meyers, L. A., \& Zhou, J. (2012). The failure to remediate previously disclosed material weaknesses in internal controls. Auditing: A Journal of Practice \& Theory, 31(2), 73-111.

Hoitash, R., Hoitash, U., \& Bedard, J. C. (2008). Internal control quality and audit pricing under the Sarbanes-Oxley Act. Auditing: A Journal of Practice \& Theory, 27(1), 105-126.

Knechel, W. R., Krishnan, G. V., Pevzner, M., Shefchik, L. B., \& Velury, U. K. (2013). Audit quality: Insights from the academic literature. Auditing: A Journal of Practice \& Theory, 32(1), 385-421.

Krishnan, J., Rama, D., \& Zhang, Y. (2008). Costs to comply with SOX Section 404. Auditing: A Journal of Practice \& Theory, 27(1), 169-186.

Leuz, C., Nanda, D., \& Wysocki, P. (2003). Earnings management and investor protection: An international comparison. Journal of Financial Economics, 69(3), 505-527.

Nanda, D., \& Wysocki, P. (2011). The relation between trust and accounting quality. Working Paper, University of Miami School of Business.

Nishizaki, R., Takano, Y., \& Takeda, F. (2014). Information content of internal control weaknesses: The evidence from Japan. The International Journal of Accounting, 49(1), 1-26.

Ogneva, M., Subramanyam, K. R., \& Raghunandan, K. (2007). Internal control weakness and cost of equity: Evidence from SOX Section 404 disclosures. The Accounting Review, 82(5), 1255-1297.

Raghunandan, K., \& Rama, D. V. (2006). SOX Section 404 material weakness disclosures and audit fees. Auditing: A Journal of Practice \& Theory, 25(1), 99-114.

Skinner, D. J., \& Srinivasan, S. (2012). Audit quality and auditor reputation: Evidence from Japan. The Accounting Review, 87(5), $1737-1765$. 